\title{
JÉRÔME MEIZOZ. POSTURAS LITERARIAS. PUESTAS EN ESCENA MODERNAS DEL AUTOR
}

POR

\author{
Esther Fernández Cifuentes
}

Universitat Autònoma de Barcelona

El libro del investigador suizo Jérôme Meizoz (Université de Lausanne), publicado originalmente en francés en 2007, propone la noción de postura autorial-sistematizada por este en 2001 y retomada en 2011 (La fabrique des singularités. Postures Littéraires II. Ginebra y París: Slatkin Erudition)- para referirse al que considera un elemento fundamental de la creación literaria: la presentación pública que el autor hace de sí mismo tanto en la obra como en el espacio literario y cultural. La traducción de Juan Zapata, que también firma el prólogo de la presente edición, tiene como fin poner este concepto y sus posibilidades para el análisis a disposición del corpus literario hispanoamericano.

A lo largo de diez capítulos, Meizoz describe la idea de postura, situándola primero en relación a la teoría literaria para abordar después su disección en los distintos casos de estudio, pertenecientes a la literatura autobiográfica francesa de entre los siglos XVIII y XX. De forma dialogada, el primero de los capítulos ofrece las definiciones del término, presentado como "la manera singular que un autor tiene de ocupar una posición en el campo literario" (12) o como una "identidad literaria construida por el autor mismo y, en la mayoría de los casos, retomada por los medios, que la ponen a disposición del público". La postura, por tanto, recogería tanto elementos del orden de la sociología, como la conducta social, cuanto de la retórica, referentes al texto o discurso. Necesita, pues, de un análisis que exceda al texto y aborde a su vez toda conducta pública que tenga lugar en la institución literaria. Meizoz aclara que, aunque toda postura se pretende singular, en realidad ocupa un lugar transicional entre lo individual y lo colectivo, y señala hacia lo que llama familias posturales, estrechamente vinculadas a las prácticas históricas y que quedan a disposición de los autores para su adopción.

En el segundo apartado, el teórico escribe una historia del concepto de autor, en auge durante lo que Nathalie Heinich llama el régimen de singularidad, vinculado a la modernidad y al nuevo estatuto del artista como creador. A continuación, Meizoz repasa las distintas corrientes críticas que debaten y cuestionan esta herencia en el siglo XX, como el formalismo ruso, el estructuralismo o la nueva crítica, para acercarse después 
a las aportaciones del análisis del discurso. El pensador diferencia dos tendencias principales para abordar tal noción: las teorías que leen al autor como equivalente de la persona y aquellas que separan a la persona civil del proceso de significación, entendiendo el texto como unidad de sentido, e indica que solo en la década de los noventa del siglo pasado se presenta una síntesis entre ambos posicionamientos. En esta primera parte del libro, Meizoz escribe sobre las teorías y conceptos que preceden al de postura, como los de ethos, imagen de autor o escenografía autorial, mientras despliega sus aportaciones originales.

En el tercer episodio, Meizoz descubre el primero de los casos particulares, en el que revela la contribución de los ideales democráticos modernos a la puesta en circulación de la postura del pobre benemérito, reconstruida a partir de los textos de Jean-Jacques Rousseau y de Stendhal. Así, las ideas modernas de mérito y ambición circulan en textos como las Confesiones (1782), escritas en primera persona por un Rousseau que se muestra como aspirante a intelectual en una sociedad prerrevolucionaria en la que la corte ha secuestrado tal posibilidad. La novela de la meritocracia, que recurre a las historias de ambición y ascenso social, vive su auge durante los años treinta del siglo XIX, en los que la monarquía se acerca a los ideales burgueses. Así, Rojo y negro (1830), de Stendhal, retoma el motivo propuesto por Rousseau y lo ficcionaliza de forma irónica, poniendo de manifiesto las tensiones y paradojas inherentes a un proyecto democrático que reclama igualdad formal y mérito a la vez que llama a la ambición y a la distinción, haciendo de su personaje Julien Sorel, al que se equipara con Rousseau, un sujeto incapaz de escapar a la alienación y al arcaísmo al que le conducen inevitablemente sus fantasías de progreso.

La humildad del origen social vuelve a estar en el centro de la segunda postura autorial propuesta por el teórico suizo, esta vez ejemplificada a través de Charles Péguy y Charles Ferdinand Ramuz. Si Rousseau buscaba redimir su humilde pasado mediante el saber intelectual, Péguy y Ramuz invocan a la genealogía para alejarse de su estatus privilegiado, participando así del motivo de la filiación desclasada. El retorno a los orígenes al que llama Péguy supone dejar atrás la estética de los salones literarios parisinos y abrazar la lengua de los campesinos del Beauce, lo que transformará tanto su prosa como su postura. Influenciado por este, Ramuz vive de manera problemática su actividad literaria hasta el punto de rechazar el estatus social que se la posibilita; en cambio, busca identificarse con la generación de sus abuelos, campesinos y viñadores. Con este fin, en sus diarios, reescribe su propia historia, elidiendo a sus progenitores y el ascenso social que protagonizan. En su intento por desmarcarse del intelectualismo burgués, reivindica la escritura como actividad artesanal, así como la lengua y cultura campesinas, acercándose a la oralidad de la suiza normanda. Como los escritores del movimiento regionalista, Ramuz legitima su actividad literaria al convertirla en el testigo necesario de una forma de cultura popular, adoptando la que Meizoz llama la postura del escriba de la tribu.

$111 \frac{\text { Revista Iberoamericana, Vol. LXXXV, Núm. 268, Julio-Septiembre 2019, } 1069-1072}{\text { ISSN 2154-4794 (Electrónico) }}$ 
La unión entre postura de autor y enunciación literaria en Péguy y Ramuz inspiran a Henry Poulaille, que contribuye a situar la autenticidad en el centro del movimiento y la postura proletarias, recogidas en el manifiesto de la Nouvelle âge littéraire. Para el primero, esta propiedad constituye una cualidad moral, por la que el escritor, como hiciera Rousseau, debe testimoniar su condición social; asimismo, este se debe a un orden estético distinto del artístico o burgués, por el cual se privilegia el valor documental y el registro de la lengua hablada. Esta será la solución que Poulaille proponga al conflicto del autor proletario, carente de modelo hasta el período de entreguerras, cuando aparecen distintos escritores provenientes de las clases subalternas. La noción de autenticidad redefinirá los criterios de valorización del campo literario en esos años. Meizoz repasa de qué manera escritores como Lucien Gachon, Louis Guilloux, Jean Guéhenno o Jean Giono hacen suya la postura proletaria y como esta, bajo la iniciativa de Poulaille, absorbe a figuras como Ramuz, quien termina por rebelarse contra la reorientación de su imagen pública.

El sexto y séptimo capítulo están dedicados a Louis-Ferdinand Céline y a la evolución de su postura autorial, ligada a un uso del seudónimo que delimita su despliegue. Como Poulaille, Céline cree necesaria la vinculación entre el estatuto social del escritor y el testimonio que se quiere brindar, por ello adopta un estilo oral popular que se opone a la lengua burguesa. Si en Viaje al final de la noche (1932) se presenta como un médico de pobres condenado al trabajo, en Bagatelas para una masacre (1937) destaca su franqueza y su condición de hombre perseguido por la crítica y el medio literario, igualmente se muestra como alguien nacionalista y racista; un tercer desplazamiento lo llevará, en Entrevista con el Profesor Y (1955), a adoptar la postura de la víctima virtuosa, presentándose como un hombre pobre que es rechazado por todos por expresar verdades incómodas. Este giro lo lleva a alinearse con uno de sus primeros personajes, Semmelweis, médico húngaro al que dedica su tesis de carácter biográfico en 1924; a modo de profecía autocumplida Céline termina por situarse, como su objeto, en el lugar del genio menospreciado, cuya exclusión se percibe como signo de valorización, función que Céline confía a la tarea biográfica. La biografía aparece así como un género capaz de revelar el vínculo entre el biógrafo y su personaje, en el que el primero compromete una parte de su identidad literaria.

A continuación, Meizoz introduce la postura del trotamundos, estudiada a partir de Blaise Cendrars y su novela Bourlinguer (1948). Su poética, comprometida con su postura, parte de la idea de escritura vinculada a la experiencia vital, a la relación con el mundo, lo que se traduce en un sacrificio de la ortografía y la gramática en favor de la autenticidad y la oralidad. La autoficción, protagonizada por B. C., se mueve de una biblioteca veneciana hacia el exterior, para proyectarse en los dobles Nicolao Manuci, aventurero y autor de sus memorias, y Casanova; de este modo, Cendrars vincula la escritura a los acontecimientos vividos a la vez que se muestra en deber con

$111 \frac{\text { Revista Iberoamericana, Vol. LXXXV, Núm. 268, Julio-Septiembre 2019, } 1069-1072}{\text { ISSN 0034-9631 (Impreso) }}$ 
los modelos textuales de la tradición literaria. Asimismo, critica duramente la labor de editores y traductores, ocupados en el texto de Manuci, y su experiencia mediada. El intento de asalto del aventurero sobre el literato se deja ver, al mismo tiempo, en la fotografía que Robert Doisneau le toma el año de publicación de la novela, en la que renuncia a los tópicos de representación del autor para dejarse ver en el exterior, con el rostro surcado por los años, la camisa abierta y una colilla entre los labios.

Los dos últimos capítulos se ocupan del poeta suizo Charles-Albert Cingria. En el primero se continúa explorando la relación genérica y postural, esta vez a través de la reseña que Cingria escribiera en 1933 bajo el encargo de Jean Paulhan a propósito de los textos de Leon Trotsky Historia de la Revolución Rusa y Mi vida. En ella el escritor despliega la postura del bufón, al someter los textos de Trotsky a un juicio formal que se desentiende de su contenido, de orden político, desviándose así de la intención del autor. En el segundo episodio, Meizoz recupera una declaración de Cingria de 1947 en la que apunta a su admiración por el también poeta Aragon, perteneciente a los círculos comunistas y en las antípodas de su propio posicionamiento político. Meizoz señala que la postura burlesca de Cingria sería una reacción a la repentina politización del campo literario, una invitación a disociar el juicio artístico de la afiliación política, así como una manera de esquivar ser asignado a una postura unívoca, como atestigua la oscilación, a lo largo de su vida literaria, entre las posturas del ciclista errante, el eremita erudito, el cronista excéntrico o el bufón.

Tras demostrar el margen de autocreación del que dispone un autor con respecto a su postura, el libro se cierra recordando la importancia que la categoría autorial tiene a la hora de determinar la particularidad, y por tanto valía, de un autor, al mismo tiempo que recuerda que son "sus acciones y sus gestos ejemplares, además de sus obras, los que se ofrecen al escritor aspirante como recursos simbólicos para existir" (169).

JÉrôMe Meizoz. Posturas literarias. Puestas en escena modernas del autor. Traducción y prólogo de Juan Zapata. Bogotá: Ediciones Uniandes, 2015. 182 pp. ISBN: 978-9-587-7420-46. 